\title{
The Effect of Aqueous Leaves Extracts of Eucalyptus camaldulensis on Germination and Growth of Three Weed Species
}

\author{
Janan A. Saeed \\ Eman R. Al-Rawi Fatin K. Ibraheem \\ Department of Biology \\ College of Science \\ University of Mosul
}

(Received 24/9/2012; Accepted 26/11/2012)

\begin{abstract}
This research included experiments in laboratory and green house to study the effect of Eucalyptus camaladulensis leaf extracts at concentrations ( 5,10 and 15$) \% \mathrm{~W}: \mathrm{V}$ on seed germination and growth of the weeds (Datura spp., Sonchus spp. and Sinapis spp.).

Laboratory experiment, showed an inhibition in germination and seedling growth as the aqueous extracts concentration increased. The maximum inhibition in (germination, plumule length and weight) reaching $(30.51,52.4,56.2) \%$ respectively in Sinapis, while the maximum inhibition in radical growth $(55.5,53.5) \%$ was shown in Datura at $(15 \%)$.

Green house results also showed that the highest inhibition $(26.96,58.66,45.6) \%$ respectively in germination and (shoot length and weight)in Sinapis at (15\%), and high inhibition in (root length and weight) was $(56.97,75.7) \%$ in Datura at $(15 \%)$. The Results were accompanied with the inhibition in the content of N, P, K maximum inhibition of $\mathrm{N}$ content (58.73\%) in Datura, of P content (75.47\%) in Sinapis and of K content (49.93\%) in Datura at (15\%). The content of the K increases in Sonchus at $(10,15) \%$ and in Sinapis at (15\%). It was also shown that the weeds differ in their response to the allelopathic effect of Eucalyptus leaves extracts,indicating that Sinapis weed was sensitive whereas Sonchus seems to be resistant.
\end{abstract}

Keywords: Allelopathy, Eucalyptus camaldulensis, Weeds.

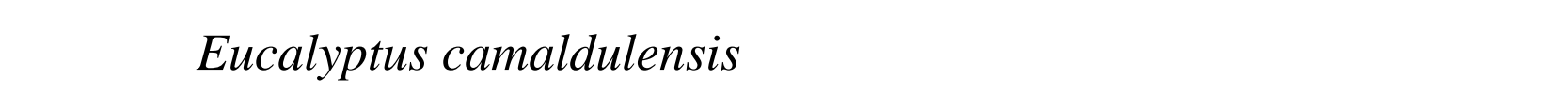

البور والنمو الثلانة ألنواع من الأدغل

\section{الملغص}

تضمن البهث لجراء تجارب في المختبر والبيت الزجلجي لدرلسة تأثير اضضفة الم ستخلص الم ائي

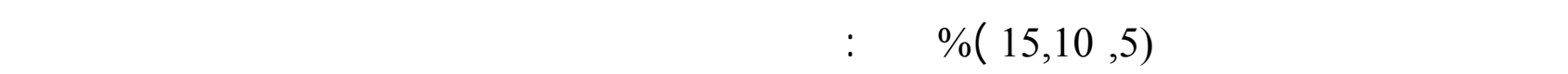
(Datura,Sonchus and Sinapis)

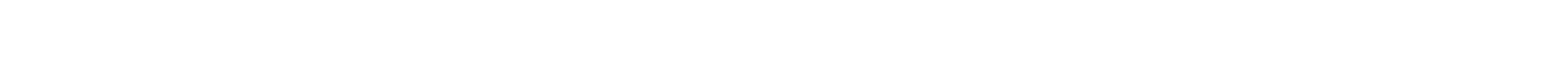
المستخلص المائي حيث كلت أعلى نسبة في الإنبلت،طول الرويشة ووزنها الجلف (56.2,52.4,30.51 )\% 


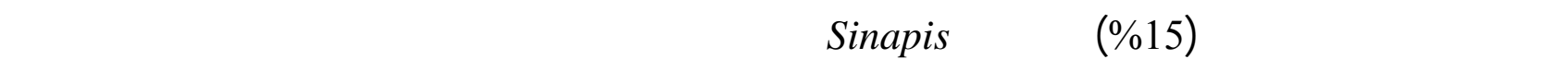

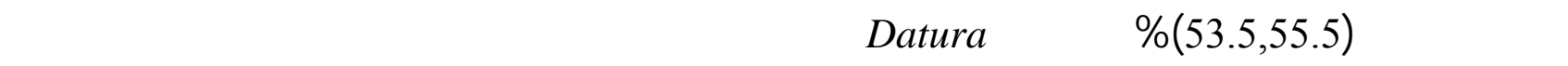

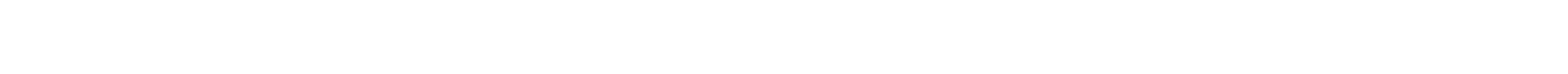

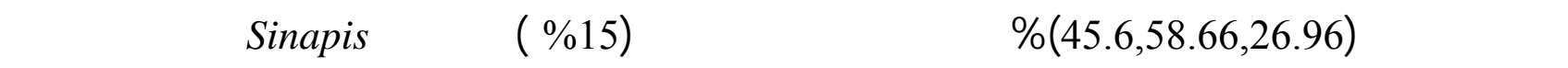

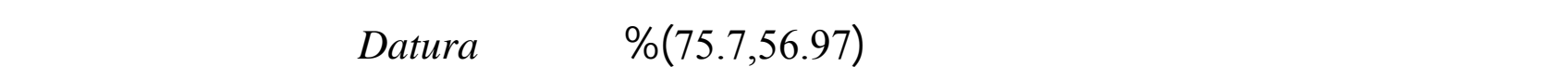
المستخلص. ترافتت هذه النتائج مع حصول لختزل في ترلكيز) (N,P,K) في الأدغل الثلاثة فقد بلغت أعل م ف سسبة

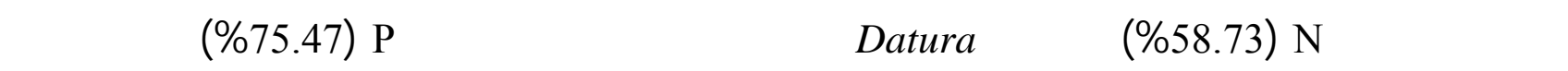
أنinapis

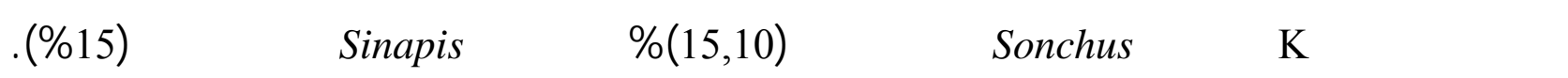

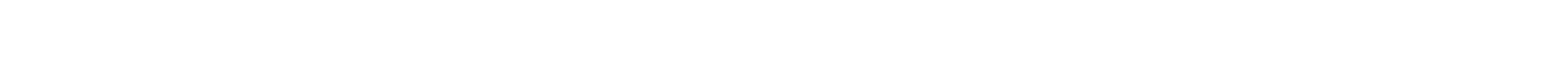

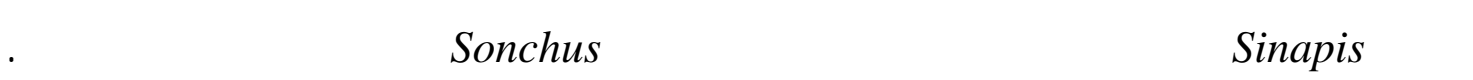

\section{INTRODUCTION}

Allelopathy is an important mechanism of plant interference mediated by the additional phytotoxins to the environment, chemicals with allelopathic potential are present in virtually all plants as in most tissues. Under appropriate conditions, these chemicals may be released into the environment, in sufficient quantities to affect neighboring plants (Tahir, 2011).

Weeds are unwanted plants, non-useful persistent, effectively competing with the beneficial and desirable plant for space, nutrients, sunlight and water (Mandal, 2000).

Several researches conducted on many species of forest trees such as (Acacia, Eucalyptus and Walnut) trees produce allelochemicals that could be suppress the growth and germination of other crops and weeds growing near to it (El-Khwas and Shehata 2005 and Tahir, 2011).

Eucalyptus camaldulensis belongs to the family myrtaceae. It is a large perennial woody tree having distinctive glaucoushue and its leaves has shown allelopathic activity representative of a wide variety of plants capable of establishing gradients of toxicity in an otherwise uniform environment. Such gradients drastically alter the species composition and thus are highly important to the study of vegetative composition. (Inouye et al., 2001).

Putnam (1984) reported that Eucalyptus species released volatile compound such as benzoic, cinnamic and phenolic acids which inhibit the growth of some crops and weeds near to it. Several studies were applied in this field. El-Rokiek and Eid (2009) documented that aqueous extracts of fresh and dry leaves of Eucalyptus citriodora reduced the germination and seedling growth of wild Oat weed (Avena fatua L.).

The inhibitory effects on weeds were correlated with the accumulation of the internal contents of total phenols compared to their respective controls. Dadkhah and Assadi (2010) studied the allelopathic effects of Eucalyptus camaldulensis on seed germination and seedling growth of Acroptilon repens, Plantago lanceolata and Portulaca oleracea and 
revealing that maximum inhibition of germination percentage, rate of germination and seedling growth were recorded when using the highest concentration of the aqueous extract $20 \mathrm{gL}^{-1}$ of Eucalyptus leaves. Dadkhah (2012) reported that the shoot aqueous extract of Eucalyptus, Sunflower and sugerbeet caused inhibition in germination growth and photosynthesis of the Amaranthus retroflexus. Majeed and Ali (2012) found that aqueous extract effect of Schanginia aegyptiuca has an adverse effect on germination and seedling growth of Rossella (Hibiscus sabdariffa L.).

This study aimed to evaluate the effect of aqueous extract of Eucalyptus leaves against three weeds included (Datura spp., Sonchus spp. and Sinapis spp.).

\section{MATERIALS AND METHODS}

The experiments were conducted to determine the allelopathic effect of aqueous extracts of Eucalyptus camaldulensis leaves at the concentrations $(5,10,15) \% \mathrm{~W}: \mathrm{W}$ on seed germination and growth of three weeds (Datura spp., Sonchus spp. and Sinapis).

\section{Aqueous extracts preparation:-}

Eucalyptus camaldulensis fresh leaves were collected from Mosul university at 2010, the fresh leaves were washed with tap water, followed by distilled water to remove the dust, then three weights of fresh leaves $(5,10,15)$ gm were homogenized with $100 \mathrm{ml}$ of distilled water by blender, then filtrated through Whatman No.1 filter paper, a Petri dish assay was carried out for screening the effect of different concentrations of aqueous extracts of Eucalyptus on germination and seedling growth of three weeds (El-Khawas and Shehata, 2005).

\section{Bioassay of the Eucalyptus leaves extract}

A Petri dish assay was carried out for screening the effect of E. camaldulensis leaf aqueous extracts at $(5,10,15) \% \mathrm{w}: \mathrm{v}$ on germination and seedling growth of three weed species included (Datura spp., Sonchus spp. and Sinapis spp.), 50 seeds of each weed (pre-tested seed 90\% germination abilities) were evenly disturbed between 2 layers of Whatman no. 1 filter paper in each $13 \mathrm{~cm}$. Petri dish, then $6 \mathrm{ml}$. of each concentration of the extracts was added to each Petri dish, using the same quantity of distilled water as control. 5 replicates were used in each treatment. Germination was carried out in a cool incubator (Galenkhamp) at average temperature $25 \mathrm{c} \pm 2$.

After 7 days germination percentage $\%$ was recorded, Plumule and radical length were recorded after 14 days, samples were dried in the oven at $70 c^{\circ}$ for $72 \mathrm{~h}$. to get their dry weights.

$$
\text { Germination percentage }=\frac{\text { No. of germinated seeds }}{\text { No. of cultivated seeds }} \quad \text { x } 100 \text { (ISTA 1976). }
$$

\section{Pot experiments:-}

Pot experiments were conducted at the green house in(20/12/2010). The pots of $(17 \times 15) \mathrm{cm}$ in diameter and height were used, filled with mixture soil (loamy sand), 10 seeds of each of the tested weeds were sown in each pot at $1 \mathrm{~cm}$ depth, then irrigated with $50 \mathrm{ml}$ of Eucalyptus extracts at $(5,10,15) \% \mathrm{w}: \mathrm{v}$ using distilled water for control .

The pots were arranged in a (R.C.B.D.) design with 5 replicates to each treatment, after 2 weeks of planting the number of germinating seeds were recorded, then plants were irrigated with $50 \mathrm{ml}$ of the extract concentration every 2 weeks. During the experiment 
period (after 60 days of germination, the plants were harvested, shoot and root length as well as their dry weights were recorded.

\section{Determination of $\mathbf{N}, \mathbf{P}, \mathbf{K}$ content}

$\mathrm{N}, \mathrm{P}, \mathrm{K}$ content were determined in dried leaves of the tested weeds according to the official and modified methods of analysis(AoAc.,1983).

1-Nitrogen: Depend on using Micro-kjeldal method ( Bremner,1965)

2- Phosphrus: By using Spectrophotometer (Matt,1970).

3-Potassium: By using flame photometer (Richards, 1965).

Statistical analysis

The data for all characters were analyzed using of various procedures of statistical analysis system (SAS) software version. Means were compared by Duncans multiple range tests at 0.05 probability level for all comparisons (Steel and Torrie, 1990).

\section{RESULTS}

The results in Table (1) showed significant inhibition in seed germination of the three weed species treated with Eucalyptus extracts at the concentrations (10 and 15\%). As compared with distilled water (control), also seedling growth of the weeds affected with Eucalyptus extracts showing reduction in the plumule and radical lengths and their dry weights. As we see that the effect of the aqueous extracts depends on their concentrations, the highest reduction was noticed at (10 and 15)\%, while the lowest reduction was recorded at $5 \%$, rather than the significant difference between treatments.

\section{Table1: The effect of Eucalyptus leaves extracts on germination and seedling growth of (Datura spp., Sonchus spp. and Sinapis spp.)}

\begin{tabular}{|c|l|l|l|l|l|l|}
\hline $\begin{array}{c}\text { Weed } \\
\text { species }\end{array}$ & concentration & $\begin{array}{c}\text { Germination } \\
\text { \% }\end{array}$ & $\begin{array}{c}\text { Plumule } \\
\text { length(cm) }\end{array}$ & $\begin{array}{c}\text { Radicle } \\
\text { length(cm) }\end{array}$ & $\begin{array}{c}\text { Plumule } \\
\text { dry weight } \\
\text { (mg) }\end{array}$ & $\begin{array}{c}\text { Radicle dry } \\
\text { weight (mg) }\end{array}$ \\
\hline \multirow{5}{*}{ Datura } & control & $* 99.24 \mathrm{a}$ & $6.6 \mathrm{a}$ & $7.2 \mathrm{a}$ & $5.8 \mathrm{a}$ & $4.5 \mathrm{a}$ \\
\cline { 2 - 7 } & $5 \%$ & $86.70 \mathrm{ab}$ & $5.7 \mathrm{ab}$ & $6.1 \mathrm{ab}$ & $5.0 \mathrm{ab}$ & $4.0 \mathrm{a}$ \\
\cline { 2 - 7 } & $10 \%$ & $77.50 \mathrm{~b}$ & $4.5 \mathrm{~b}$ & $4.8 \mathrm{~b}$ & $4.1 \mathrm{~b}$ & $3.5 \mathrm{~b}$ \\
\cline { 2 - 7 } & $15 \%$ & $66.40 \mathrm{c}$ & $3.7 \mathrm{c}$ & $3.2 \mathrm{c}$ & $3.0 \mathrm{c}$ & $2.1 \mathrm{c}$ \\
\hline \multirow{4}{*}{ Sonchus } & control & $92.30 \mathrm{a}$ & $5.6 \mathrm{a}$ & $6.3 \mathrm{a}$ & $5.1 \mathrm{a}$ & $4.2 \mathrm{a}$ \\
\cline { 2 - 7 } & $10 \%$ & $85.60 \mathrm{ab}$ & $4.9 \mathrm{ab}$ & $5.4 \mathrm{ab}$ & $4.5 \mathrm{ab}$ & $4.0 \mathrm{a}$ \\
\cline { 2 - 7 } & $15 \%$ & $78.70 \mathrm{~b}$ & $3.8 \mathrm{~b}$ & $3.9 \mathrm{~b}$ & $3.5 \mathrm{~b}$ & $3.6 \mathrm{a}$ \\
\hline \multirow{5}{*}{ Sinapis } & control & $70.10 \mathrm{~b}$ & $2.7 \mathrm{c}$ & $3.2 \mathrm{~b}$ & $2.8 \mathrm{c}$ & $2.4 \mathrm{c}$ \\
\cline { 2 - 7 } & $5 \%$ & $89.80 \mathrm{a}$ & $6.1 \mathrm{a}$ & $7.0 \mathrm{a}$ & $4.8 \mathrm{a}$ & $4.1 \mathrm{a}$ \\
\cline { 2 - 7 } & $10 \%$ & $84.20 \mathrm{ab}$ & $5.8 \mathrm{a}$ & $6.1 \mathrm{ab}$ & $4.0 \mathrm{a}$ & $4.0 \mathrm{a}$ \\
\cline { 2 - 7 } & $15 \%$ & $62.10 \mathrm{~b}$ & $4.7 \mathrm{~b}$ & $5.0 \mathrm{~b}$ & $3.0 \mathrm{~b}$ & $2.2 \mathrm{~b}$ \\
\hline
\end{tabular}

*Means within the same letter for each plant are not significant different at 0.05 level according to Duncan's multiple rang test.

Table (2) presented the percentage inhibition compared with the control of germination and the seedling growth (plumule and radical) of the tested weeds, showing that the highest 
inhibition was shown in Sinapis seeds treated with Eucalyptus extracts at the concentration $15 \%$ reaching $(30.5 \%)$ in germination, in plumule length and weight reaching $(52.4,56.2) \%$ respectively, while the highest inhibition in radical growth was shown in Datura which reached $(55.5,53.5) \%$ respectively, but the lowest inhibition in germination and seedling growth shown in Sinapis reaches $(6.23,4.91,12.8,2.43) \%$ respectively.

Table 2 :Inhibition percentage\% of germination and seedling growth of (Datura spp. Sonchus spp. and Sinapis spp.) affected by Eucalyptus leaves extracts

\begin{tabular}{|l|l|l|l|l|l|l|}
\hline $\begin{array}{l}\text { Weed } \\
\text { species }\end{array}$ & concentration & $\begin{array}{l}\text { Germination } \\
\text { \% }\end{array}$ & $\begin{array}{l}\text { Plumule } \\
\text { length }\end{array}$ & $\begin{array}{l}\text { Radicle } \\
\text { length }\end{array}$ & $\begin{array}{l}\text { Plumule } \\
\text { dry weight }\end{array}$ & $\begin{array}{l}\text { Radicle } \\
\text { dry weight }\end{array}$ \\
\hline \multirow{5}{*}{ Datura } & $5 \%$ & 12.6 & 13.6 & 15.2 & 13.7 & 11.1 \\
\cline { 2 - 7 } & $10 \%$ & 21.9 & 31.8 & 33.3 & 29.3 & 22.2 \\
\cline { 2 - 7 } & $15 \%$ & 33.09 & 43.9 & 55.5 & 48.2 & 53.3 \\
\hline \multirow{3}{*}{ Sonchus } & $5 \%$ & 7.25 & 12.5 & 14.28 & 11.76 & 4.76 \\
\cline { 2 - 7 } & $10 \%$ & 14.73 & 32.14 & 38.09 & 31.09 & 14.28 \\
\cline { 2 - 7 } & $15 \%$ & 24.05 & 51.78 & 49.20 & 45.09 & 42.85 \\
\hline \multirow{3}{*}{ Sinapis } & $5 \%$ & 6.23 & 4.91 & 12.85 & 16.66 & 2.43 \\
\cline { 2 - 7 } & $10 \%$ & 19.71 & 22.95 & 28.57 & 37.5 & 46.34 \\
\hline
\end{tabular}

The results presented in Table(3) indicated that the seeds of the weed species which sown in the soils irrigated with Eucalyptus leaves extracts were failed to germinate as compared with distilled water (control), the maximum inhibition was caused by $15 \%$ of the extracts. Also weed growth were reduced significantly, showing significant difference between the weeds shoot, root lengths and dry weights of the treated weeds grown in the soil irrigated with Eucalyptus leaves extracts, maximum reduction caused by $15 \%$, while the lowest reduction shown in 5\% concentration.

Table 3: The effect of Eucalyptus leaves extracts on germination and growth of (Datura spp., Sonchus spp. and Sinapis spp.)

\begin{tabular}{|c|l|l|l|l|l|l|}
\hline $\begin{array}{c}\text { Weed } \\
\text { species }\end{array}$ & concentration & $\begin{array}{c}\text { Germination } \\
\text { \% }\end{array}$ & $\begin{array}{c}\text { Shoot } \\
\text { length } \\
\text { (cm) }\end{array}$ & $\begin{array}{c}\text { Root length } \\
\text { (cm) }\end{array}$ & $\begin{array}{c}\text { Shootdry } \\
\text { weight } \\
\text { (mg) }\end{array}$ & $\begin{array}{c}\text { Root dry } \\
\text { weight } \\
\text { (mg) }\end{array}$ \\
\hline \multirow{5}{*}{ Datura } & control & $* 92 \mathrm{a}$ & $13.7 \mathrm{a}$ & $19.0 \mathrm{a}$ & $50.2 \mathrm{ab}$ & $88.5 \mathrm{a}$ \\
\cline { 2 - 7 } & $5 \%$ & $85 \mathrm{ab}$ & $13.0 \mathrm{a}$ & $18.0 \mathrm{a}$ & $41.3 \mathrm{ab}$ & $69.8 \mathrm{ab}$ \\
\cline { 2 - 7 } & $10 \%$ & $78 \mathrm{~b}$ & $11.4 \mathrm{~b}$ & $15.1 \mathrm{~b}$ & $33.2 \mathrm{~b}$ & $47.6 \mathrm{~b}$ \\
\cline { 2 - 7 } & $15 \%$ & $70 \mathrm{~b}$ & $9.0 \mathrm{c}$ & $11.8 \mathrm{c}$ & $21.6 \mathrm{c}$ & $21.5 \mathrm{c}$ \\
\hline \multirow{5}{*}{ Sonchus } & $\mathrm{control}$ & $90 \mathrm{a}$ & $17.5 \mathrm{a}$ & $20.1 \mathrm{a}$ & $64.1 \mathrm{a}$ & $251.5 \mathrm{a}$ \\
\cline { 2 - 7 } & $5 \%$ & $80 \mathrm{~b}$ & $15.1 \mathrm{~b}$ & $18.7 \mathrm{~b}$ & $55.2 \mathrm{a}$ & $191.2 \mathrm{~b}$ \\
\cline { 2 - 7 } & $10 \%$ & $74 \mathrm{~b}$ & $13.5 \mathrm{c}$ & $16.5 \mathrm{c}$ & $42.1 \mathrm{~b}$ & $161.1 \mathrm{~b}$ \\
\cline { 2 - 7 } & $15 \%$ & $68 \mathrm{c}$ & $11.8 \mathrm{~d}$ & $12.1 \mathrm{c}$ & $37.2 \mathrm{c}$ & $121.2 \mathrm{c}$ \\
\hline \multirow{5}{*}{ Sinapis } & $\mathrm{control}$ & $89 \mathrm{a}$ & $7.5 \mathrm{a}$ & $12.5 \mathrm{a}$ & $192 \mathrm{a}$ & $181.7 \mathrm{a}$ \\
\cline { 2 - 7 } & $5 \%$ & $80 \mathrm{~b}$ & $6.8 \mathrm{a}$ & $9.9 \mathrm{~b}$ & $155 \mathrm{~b}$ & $181.2 \mathrm{a}$ \\
\cline { 2 - 7 } & $10 \%$ & $70 \mathrm{c}$ & $5.0 \mathrm{~b}$ & $8.7 \mathrm{bc}$ & $127 \mathrm{~b}$ & $121.5 \mathrm{~b}$ \\
\cline { 2 - 7 } & $15 \%$ & $65 \mathrm{c}$ & $3.1 \mathrm{c}$ & $6.8 \mathrm{c}$ & $97.6 \mathrm{c}$ & $85.6 \mathrm{c}$ \\
\hline
\end{tabular}


when we compare the percentage of inhibition in the Table (4) it was clear that the maximum inhibition in seed germination, shoot and root lengths showed in Sinapis is reaching $(26.9,58.6,45.6) \%$ respectively, but in the shoot and root dry weights reached (56.97 and 75.7 )\% in Datura by the concentration 15\% of the Eucalyptus extracts.

Table 4: Inhibition percentage\% of germination and growth of (Datura spp., Sonchus spp. and Sinapis spp.) affected by Eucalyptus leaves extracts

\begin{tabular}{|c|l|l|l|l|l|l|}
\hline $\begin{array}{c}\text { Weed } \\
\text { species }\end{array}$ & concentration & Germination \% & $\begin{array}{c}\text { Shoot } \\
\text { length }\end{array}$ & $\begin{array}{c}\text { Root } \\
\text { length }\end{array}$ & $\begin{array}{c}\text { Shoot dry } \\
\text { weight }\end{array}$ & $\begin{array}{c}\text { Root dry } \\
\text { weight }\end{array}$ \\
\hline \multirow{4}{*}{ Datura } & $5 \%$ & 7.60 & 5.10 & 5.26 & 17.72 & 21.12 \\
\cline { 2 - 7 } & $10 \%$ & 15.21 & 16.78 & 20.52 & 33.86 & 46.21 \\
\cline { 2 - 7 } & $15 \%$ & 23.91 & 34.30 & 37.89 & 56.97 & 75.70 \\
\hline \multirow{4}{*}{ Sonchus } & $5 \%$ & 11.11 & 13.71 & 6.96 & 13.88 & 23.97 \\
\cline { 2 - 7 } & $10 \%$ & 17.77 & 22.85 & 17.91 & 34.32 & 35.94 \\
\cline { 2 - 7 } & $15 \%$ & 24.44 & 32.57 & 39.80 & 41.96 & 51.80 \\
\hline \multirow{3}{*}{ Sinapis } & $5 \%$ & 10.11 & 9.33 & 20,8 & 19.27 & 0.27 \\
\cline { 2 - 7 } & $10 \%$ & 21.34 & 33.33 & 30.4 & 33.85 & 33.13 \\
\cline { 2 - 7 } & $15 \%$ & 26.96 & 58.66 & 45.6 & 49.16 & 52.88 \\
\hline
\end{tabular}

This reduction in the growth of the tested weeds was accompanied with significant reduction in the shoot content of $(\mathrm{N}, \mathrm{P}, \mathrm{K})$ shown in Table (5 and 6), as we see the significant difference between the treatments, indicating that the decline in $\mathrm{N}$ content reached the maximum (58.7\%) in Datura. the $\mathrm{P}$ content, the highest reduction reached (75.4\%) in Sinapis, K content decline in Datura reaching (49.9\%). The maximum inhibition of $(\mathrm{N}, \mathrm{P}, \mathrm{K})$ shown at $(15 \%)$ of the Eucalyptus extracts. While in Sonchus showed an increase in $\mathrm{K}$ at $(10,15) \%$, in Sinapis at (15\%) compared with the control. while the content of $\mathrm{K}$ increased in Sonchus at the concentrations (10 and 15\%) of Eucalyptus leaves extracts recording $(23.85,26.78) \%$ respectively. 
Table 5: The effect of Eucalyptus leaves extracts on (N,P,K) content in (Datura spp., Sonchus spp. and Sinapis spp.).

\begin{tabular}{|c|c|c|c|c|}
\hline $\begin{array}{l}\text { Weed } \\
\text { species }\end{array}$ & $\begin{array}{l}\text { Extracts } \\
\text { concentration }\end{array}$ & N\% & $\mathbf{P} \%$ & K\% \\
\hline \multirow{4}{*}{ Datura } & control & $0.63 a$ & $0.0115 a$ & $6.35 a$ \\
\hline & $5 \%$ & $0.63 \mathrm{a}$ & $0.0092 b$ & $5.25 \mathrm{ab}$ \\
\hline & $10 \%$ & $0.42 b$ & $0.0066 \mathrm{c}$ & $3.31 b$ \\
\hline & $15 \%$ & $0.26 \mathrm{c}$ & $0.0047 \mathrm{~d}$ & $3.179 b$ \\
\hline \multirow{4}{*}{ Sonchus } & control & $0.422 \mathrm{a}$ & $0.0095 a$ & $5.45 b$ \\
\hline & $5 \%$ & $0.361 \mathrm{ab}$ & $0.0082 b$ & $5.11 \mathrm{~b}$ \\
\hline & $10 \%$ & $0.252 b$ & $0.0034 c$ & $6.75 a$ \\
\hline & $15 \%$ & $0.189 \mathrm{c}$ & $0.0033 c$ & $6.91 \mathrm{a}$ \\
\hline \multirow{4}{*}{ Sinapis } & control & $0.78 \mathrm{a}$ & $0.0159 a$ & $3.802 \mathrm{a}$ \\
\hline & $5 \%$ & $0.71 \mathrm{a}$ & $0.0117 \mathrm{a}$ & $3.129 b$ \\
\hline & $10 \%$ & $0.62 b$ & $0.0075 b$ & $3.55 b$ \\
\hline & $15 \%$ & $0.46 \mathrm{c}$ & $0.0039 c$ & $4.21 \mathrm{a}$ \\
\hline
\end{tabular}

Table 6: Inhibition percentage \% of ( N,P,K)content in (Datura spp., Sonchus spp. and Sinapis spp.) affected by Eucalyptus leaves extracts.

\begin{tabular}{|l|l|l|l|l|}
\hline \multirow{2}{*}{ Weed species } & Extracts concentration & $\mathbf{N \%}$ & $\mathbf{P \%}$ & $\mathbf{K \%}$ \\
\hline \multirow{3}{*}{ Datura } & $5 \%$ & 0 & 20.00 & 17.32 \\
\cline { 2 - 5 } & $10 \%$ & 33.33 & 42.60 & 47.87 \\
\cline { 2 - 5 } & $15 \%$ & 58.73 & 59.13 & 49.93 \\
\hline \multirow{3}{*}{ Sonchus } & $5 \%$ & 14.45 & 13.68 & 6.23 \\
\cline { 2 - 5 } & $10 \%$ & 40.28 & 64.21 & +23.85 \\
\cline { 2 - 5 } & $15 \%$ & 55.21 & 65.26 & +26.78 \\
\hline \multirow{3}{*}{ Sinapis } & $5 \%$ & 8.97 & 26.41 & 17.70 \\
\cline { 2 - 5 } & $10 \%$ & 20.5 & 52.83 & 6.62 \\
\cline { 2 - 6 } & $15 \%$ & 41.02 & 75.47 & +10.73 \\
\hline
\end{tabular}

$(+)$ increase of control

\section{DISCUSSION}

Weeds are one of the major constraints to plant production worldwide, affect plant growth and production that may be reduced significantly when weeds compete with them for light, water and minerals (Hussein, 2001).

The results of laboratory experiment indicated that the aqueous extract of Euccalyptus leaves (10 and 15)\% caused inhibition in germination and seedling growth of the weed 
species as compared with distilled water. The maximum inhibition caused by the (15\%) of the extracts which agreed with (Batish et al., 2004) who found that germination, seedling length, chlorophyll content and respiratory ability of weed were rustically affected by Eucalyptus extracts. The results also showed that the radical growth is sensitive more than plumule, because the maximum inhibition in radical reached $(55.5 \%)$, in plumule $(52 \%)$. Khan et al.,(2008) reported that the aqueous extract of Eucalyptus camaldulensis leaves caused reduction in germination and seedling growth of six weed species.

Also pot experiments showed agreement with the laboratory conditions because the extracts of Eucalyptus leaves reduced seed germination and growth of the tested weeds. This inhibitory effect of the leaves extracts may be due to the allelochemical which is found in Eucalyptus leaves. Iqbal et al., (2003) reported that Eucalyptus species has a high potential of allelochemicals in the form of essential oils and found 16 compounds in the essential oil of Eucalyptus camaldulensis five of the compounds identified as ( $\alpha$-pinene, $\beta$ phellan drene.,1-8 cineole and p-cymene). Ghafar et al., (2000) found that these allelochemicals and volatile compounds presented in all parts of Eucalyptus camaldulensis have harmful effect on the crops in the ecosystem resulting in the reduction and delaying of seed germination and reduction in growth.

The growth inhibition of the treated weeds affected by Eucalyptus leaves extracts indicating that maximum inhibition by the concentration $(15 \%)$, which agreed with Singh et al., (2006) who reported that biological activities of receiver plants to allelochemicals are known to be concentration dependent on a response threshold is characteristically inhibition as the concentration increases.

The plant roots exposed to allelochemicals became brownish and avoid of root hairs formation. This might be due to the rapid inhibiting effect on the respiration of root tips which ultimately reduced elongation ( Al-Shahid et al., 2006).

Bais et al., (2003) reported that catechin a putative phytotoxin inhibits plant growth due to sever oxidative burst in root tips, resulting in cell death, Niakan and Saberi, (2009) indicated that the growth (shoot and root length and weight) of Phalaris were decreased when exposed to Eucalyptus extracts at $(5,15,30) \%$ w:v. concentrations.

The nature of the inhibitory effect of allelochemicales to seed germination could be attributed to inhibit water absorption which is a precursor of physiological processes that should occur in seeds before germination is triggered (Dadkhah and Assadi, 2010).

The effect of allelopathy on germination and growth of plants may occur through a variety of mechanisms including a reduced mitotic activity in root and hypocotyls, suppressed hormone activity, reduced rate nutrient uptake, inhibited protein formation, decreased permeability of cell membrane and inhibition of enzyme action (Rice,1984) which may attribute to the reduction of $(\mathrm{N}, \mathrm{P}, \mathrm{K})$ content in the tested weeds in our study, also the tested weeds differ in their response which may due to the effect of the extracts on the cell permeability to the nutrients uptake, or the genetic effect, because the inhibitory compounds might have reduced the uptake of nutrient which ultimately reduced shoot growth (Peng et al., 2004). Yamane and Mizutanil, (1992) reported that all the basic plant processes such as hormonal balance protein synthesis, respiration, photosynthesis, chlorophyll formation permeability and plant water relation may be disturbed by allelopathy.

Previous studies had shown that species of trees such as Juglans nigra (Tahir, 2011) and Eycalyptus species can produce allelopathic chemicals which may be effective in 
suppressing understory vegetation and weed species, several studies have demonstrated the release of phenolic and volatile compounds in its foliage.

In the last two decades, much more work was done on plant derived compounds as environmentally safe alternatives to herbicides for the weed control (Duke et al., 2002). Using of Eucalyptus as allelopathic agent will be eco-friendly cheaper effective mode of weed control.

\section{CONCLUSION}

We can conclude from the results of our experiments that the aqueous extracts of Eucalyptus leaves caused inhibition in seed germination and growth of the three tested weeds, indicating that the effect was concentration dependent, and the root growth was inhibited more than the shoot growth. Also the three weeds differ in their response to the allelopathic effect of the Eucalyptus extracts indicating that Sinapis weed was sensitive to the Eucalyptus aqueous whereas Sonchus seems to be resistant. So we can make use of Eucalyptus leaves extract in management of some weed species.

\section{REFERENCES}

AL-Shahid, M.B. (2006). Response of wheat and its weeds to different Allelopathic plant water extracts. Pak. J. Weed Sci. Res, 12,16-68.

AoAc. (1990). "The Association of Analytical Chemists". In "Official Methods of Analysis Tanni".15th ed. Washington. D. C. P., 746 p.

Bais, H. P.; Vepachedu, R.; Gelaroy, S.; Gallaway, R. M.; Vivanco, J. M. (2003). Allelopathy and exotic plant in vasion: from molecules and genes to Species interaction. Sience, 301, 1377-1380.

Batish, D. R.; Kaur, S.; Singh, H. P.; Kohli, R. K. (2004). Herrbicidal activity of volatile oils from Eucalyptus citriodora. Proceedings of the 2nd European Allelopathy Symposium Allelopathy from Understanding to Application.

Bremner, J. M. (1965) Total nitrogen, In Method of Soil Analysis, Part 2, American Society of Agronomy, Madison, Wisconsin, U.S.A., pp.1146-1179.

Chung, I.M.; Ahn, J.K.; Yun, S. J. (2001). Assessment of allelopathic potential of coastal Bermudagrass. Agron. J., 80,557-560.

Dadkhah, A. ; Assadi, M..(2010).Allelopatic effects of Eucalyptus camldensis on germination and growth seedlings of Acroption repens, Plantago lanceolata and portulaca oleracea research. J. Biological Sciences. 5, 430-434.

Dadkhah, A. (2012). Phytotoxic effects of aqueous extracts of Eucalyptus, Sunflower and sugar beet on seed germination, growth and photosynthesis of Amaranthis retroflexus. Allelopathy J., 29, 287-296.

Duke, S.O.; Dayan, F.E.; Aliota, G.; Rongani, I.G. (2002). Chemicals from nature for weed management. Weed Sci., 50, 138-151.

El-Khawas, S.A ; Shehata, M.M. (2005). The allelopathic potentialities of Acacia nilotica and Eucalyptus rostrat L. on Monocott (Zea mays L.) and Dicot (Phaseolus vulgaris L.) plants . Biotech. J., 4, 23-34.

El-Rokiek, K.G.; Eid, R. A. (2009). Allelopathic effects of Eucalyptus citriodora on amaryllis and associated grassy weed. Planata Daniaha, 27,887-899. 
Ghafar, A.; Saleem, B.; Qureshi, M.J. (2000). Allelopathic effects of sunflower on germination and seedling growth of wheat. Pak. J. Biolo. Sci., 3,1301-1302.

Hussain, H.F. (2001). Estimation of critical period of crop-weed composition and nutrient removal by weeds in onion (Allium cepa) in sandy soil. Egypt. J. Agron., 24,43-62.

Inouye, S.T.; Takizawa, Y. (2001). Antibacterial activity of essential oil and their major constituents against respiratory tract pathogens by gaseous contact. J. Antimicrobial chemotherapy, 47,565-573.

Iqbal, Z.; Hussain, I.; Hussain, A.; Ashraf, M. Y. (2003). Genetic variability to essential oil contents and composition in five Species of Eucalyptus. Pak. J. Bot., 35, 843-852.

ISTA. (1976). Intension rules for seed testing. Seed Sci. and Tech. 34.

Khan, M. A.; Hussain, I. ; Khan, E. A. (2008). Suppressing effects of Eucalyptus camaldulensis L. on germination and seedling growth of six weeds. Pak. J. Sci. Res., 14, 201-207.

Majeed, K.A.; Ali, S.A. (2012). Effect of the Schanginia aegyptiaca on seed germination and seedling growth of Rosell(Hibiscus sabdariffa L.) Asian. J. Agricultural Research, 6, 83-90.

Mandel, R.C. (2000). Weeds, weedicide and weed control principles and Practices. Agro. Botanical Publisher, Bikaner, India.

Matt, K.J. (1970). Colourimetric determination of phosphorus in soil and plant material with ascorbic acid . Soil Sci. , 109, 214-220.

Niakan, M. ; Saberi, K. (2009). Effect of Eucalyptus camaldulensis on growth characters and antioxidant enzyme activity in Phalaris weed. Asian. J. Plant Sci., 8, 440-446.

Peng, S. L.; Wen, J.; Guo, Q.F. (2004). Mechanism and active variety of Allelochemical. Acta Bot. Sinica, 46, 757-766.

Putnam, A.R. (1984). Allelopathy chemicals.Can natural plant herbicides help control weeds. Weeds Today, 15 , 6-8.

Rice, E. L. (1984). "In Allelopathy". 2 nd Orlando, F. Academic press. 422 p.

Richards, L. A. (1965). "Diagnosis and improvement of Saline and Alkalin Soil". U.S.D.A. Handbook. pp.60-160.

Singh, H.P.; Batish, D.R.; Kaur, S.; Arora, K.; Kohli, R.K. (2006). $\alpha$-Pinene Inhibits growth and induces oxidative stress in Roots. Ann. Bot., 98, 1261-1269.

Steel, R.G.; Torrie, G.H. (1990). "Principle and Procedures of Statistics". 2nd. ed. Mc. Graw. Hill book Co Inc. Singapore., pp.172-177.

Tahir, J.F. (2011). Weeds control in forest ecosystem by the allelopathic potential of Black Walnut (Juglans nigra L.). Msc. thesis, Coll. of Agric., Duhok Univ. Duhok. Iraq.

Watson, A.K. (1991). "The Classical Approach with Plant Pathogens". TeBeet. ed. Microbial. Control of weeds. New York: Chapman and Hall, pp.3-23.

Yamane, A.H.; Mizutani, J. (1992). Alleopathy of yellow fild cress (Rorippa sylvestris) Identification and Characterization of phytotoxic constituents. J. Chem. Ecol., 18, 683-691. 